Sains Malaysiana 50(10)(2021): 2965-2975

http://doi.org/10.17576/jsm-2021-5010-11

\title{
Perubahan Fizikokimia dalam Brokoli dan Bunga Kobis semasa Penyimpanan
}

\author{
(Physicochemical Changes in Broccoli and Cauliflower during Storage)
}

\author{
Jing Yi LER, ARNidA HANi TEH* \& HAFEEDZA ABDUl RAHMAN
}

\begin{abstract}
ABSTRAK
Kualiti fizikokimia dalam sayur-sayuran berubah semasa penyimpanan. Kajian ini menentukan perubahan fizikokimia dalam brokoli dan bunga kobis semasa penyimpanan dan menentukan keadaan penyimpanan yang paling sesuai. Uji kaji ini dijalankan berdasarkan suhu penyimpanan $\left(4^{\circ} \mathrm{C}\right.$ dan $23{ }^{\circ} \mathrm{C}$ ) dan kaedah pembungkusan (tidak dibungkus dan dibungkus dengan beg plastik polietilena) berbeza sepanjang tempoh 168 jam (7 hari). Perubahan warna, kehilangan berat (PLW), kandungan kelembapan, kandungan klorofil dan aktiviti antioksidan (kandungan jumlah polifenol (TPC) dan aktiviti penyingkiran radikal bebas (DPPH)) ditentukan pada 24-, 96- dan 168- jam. Sampel disimpan pada 4 ${ }^{\circ} \mathrm{C}$ dan dibungkus mengalami kehilangan fizikokimia paling minimum berbanding disimpan pada $23{ }^{\circ} \mathrm{C}$ dan tidak dibungkus. Brokoli disimpan pada $4{ }^{\circ} \mathrm{C}$ dan dibungkus dengan beg plastik polietilena mempunyai perubahan minimum bagi warna $\left(L^{*}=40.63, a^{*}=-9.88, b^{*}=19.71\right)$, PLW (2.03\%), kelembapan (84.42\%), klorofil (2.66 mg/g) dan vitamin C $(122.05 \mathrm{mg} / 100 \mathrm{~g})$. Manakala brokoli disimpan pada $23^{\circ} \mathrm{C}$ dan dibungkus dengan beg plastik polietilena mempunyai kandungan antioksida yang lebih tinggi (171.15 mg/100 g bagi TPC, 77.66\% bagi DPPH). Bunga kobis disimpan pada $4{ }^{\circ} \mathrm{C}$ dan dibungkus dengan beg plastik polietilena mengalami perubahan fizikokimia paling minimum bagi warna $\left(L^{*}=67.63, a^{*}=-1.36, b^{*}=4.77\right)$, PLW (0.97\%), kelembapan (93.26\%), klorofil (1.22 mg/g) dan vitamin C (41.92 mg/100 g). Manakala bunga kobis disimpan pada $23{ }^{\circ} \mathrm{C}$ dan dibungkus dengan beg plastik polietilena mempunyai kandungan antioksida yang lebih tinggi (167.64 mg/100 g bagi TPC, 85.51\% bagi DPPH). Justeru, keadaan penyimpanan yang paling sesuai bagi sampel brokoli dan bunga kobis adalah pada suhu $4{ }^{\circ} \mathrm{C}$ dan dibungkus dengan beg plastik polietilena.
\end{abstract}

Kata kunci: Antioksidan; brokoli; bunga kobis; fizikokimia

\section{ABSTRACT}

Physicochemical quality in vegetables changes during storage. This study determined the physicochemical changes in broccoli and cauliflower during storage and determine the best storage condition. Experiments were conducted based on different storage temperatures $\left(4^{\circ} \mathrm{C}\right.$ and $23^{\circ} \mathrm{C}$ ) and packaging conditions (without packaging and with polyethylene plastic bag) during the period of 168 hours (7 days). Changes in colour, physiological lost in weight (PLW), moisture content, chlorophyll content, and antioxidant activity (total polyphenol (TPC) and DPPH radical scavenging activity) were measured at 24-, 96- and 168-hours. Samples stored at $4{ }^{\circ} \mathrm{C}$ and packed with polyethylene plastic bag had the minimum loss of physicochemical compared to those stored at $23{ }^{\circ} \mathrm{C}$ and without packaging. Broccoli stored at $4{ }^{\circ} \mathrm{C}$ and packed with polyethylene plastic bag had the minimum loss of colour $\left(L^{*}=40.63, a^{*}=-9.88, b^{*}=19.71\right)$, PLW (2.03\%), moisture (84.42\%), chlorophyll $(2.66 \mathrm{mg} / \mathrm{g})$ and vitamin C (122.05 $\mathrm{mg} / 100 \mathrm{~g})$. While broccoli stored at $23^{\circ} \mathrm{C}$ and packed with polyethylene plastic bag had higher antioxidant activity (171.15 mg/100 $\mathrm{g}$ for TPC, 77.66\% for DPPH). Cauliflower stored at $4^{\circ} \mathrm{C}$ and packed with polyethylene plastic bag had the minimum loss of colour ( $L^{*}=67.63, a^{*}=-1.36, b^{*}=$ 4.77), PLW (0.97\%), moisture (93.26\%), chlorophyll (1.22 mg/g) and vitamin C (41.92 mg/100 g). While cauliflower stored at $23{ }^{\circ} \mathrm{C}$ and packed with polyethylene plastic bag had higher antioxidant activity (167.64 mg/100 $\mathrm{g}$ for TPC, $85.51 \%$ for DPPH). Thus, the best storage condition for broccoli and cauliflower were with storage temperature of 4 ${ }^{\circ} \mathrm{C}$ and packed with polyethylene plastic bag.

Keywords: Antioxidant; broccoli; cauliflower; physicochemical

\section{Pengenalan}

Perubahan fizikokimia sayuran semasa penyimpanan tidak dapat dielakkan tetapi dapat dikawal melalui kawalan suhu dan jenis pembungkusan (Bastrash et al. 2003). Menurut Crisosto et al. (2008), faktor suhu menentukan kualiti semasa penyimpanan. Semakin tinggi suhu, semakin cepat proses metabolisme dan semakin pendek jangka hayat penyimpanan. Sebaliknya, 
suhu rendah meningkatkan jangka hayat penyimpanan (Cantwell \& Kasmire 2002) dan melambatkan degradasi klorofil (Manolopoulou \& Varzakas 2016). Pembungkusan berperanan sebagai penghalang terhadap wap air, oksigen dan sulfur dioksida (Van Bree et al. 2010). Kelajuan respirasi yang dipengaruhi oleh faktor suhu, merupakan petunjuk jangka hayat selepas tuai. Peningkatan suhu antara $0{ }^{\circ} \mathrm{C}$ hingga $35^{\circ} \mathrm{C}$ meningkatkan kadar respirasi dan metabolisme sayuran (Safaryani et al. 2007).

Kesan pembungkusan, masa dan suhu penyimpanan adalah faktor kritikal dalam menentukan jangka hayat sayuran (Mgaya-Kilima et al. 2015). Kajian ini dijalankan untuk menentukan kesan suhu penyimpanan dan kaedah pembungkusan yang berbeza terhadap kualiti fizikokimia brokoli dan bunga kobis sepanjang tempoh penyimpanan serta untuk menentukan keadaan penyimpanan yang paling sesuai. Dalam kajian ini, brokoli dan bunga kobis yang tergolong dalam keluarga kobis (Brassicaceae) digunakan sebagai sampel. Pengambilan sayuran daripada keluarga kobis adalah tinggi disebabkan oleh nilai nutrisinya (Podsedek 2007) dan dikaitkan dengan pengurangan risiko penyakit kronik (Paramithiotis et al. 2010).

\section{BAHAN DAN KAEDAH}

\section{BROKOLI DAN BUNGA KOBIS}

Kajian ini mereplikasi amalan biasa penyimpanan. Sampel dibeli dari pasaraya di Bangi, terus dibawa ke makmal untuk penyimpanan seperti dalam reka bentuk kajian. Batang keras dan daun dibuang, manakala bahagian lain (100 g sampel) dikisar tanpa air untuk analisis. Tiga replikasi disediakan.

\section{REKA BENTUK KAJIAN}

Reka bentuk faktorial $2 \times 2$ melibatkan dua suhu $\left(4{ }^{\circ} \mathrm{C}\right.$ dan $23^{\circ} \mathrm{C}$ ) dan dua kaedah pembungkusan (dibungkus dengan beg plastik polietilena dan tidak dibungkus) berbeza. Sampel disimpan dalam 4 keadaan yang berbeza: dibungkus dengan beg plastik polietilena dan disimpan pada $4{ }^{\circ} \mathrm{C}$; tidak dibungkus dan disimpan pada $4{ }^{\circ} \mathrm{C}$; dibungkus dengan beg plastik polietilena dan disimpan pada $23{ }^{\circ} \mathrm{C}$; dan tidak dibungkus dan disimpan pada 23 ${ }^{\circ} \mathrm{C}$. Sampel dalam beg plastik polietilena dibungkus rapi dan diikat dengan gelang getah.

\section{ANALISIS FIZIKOKIMIA \\ PENENTUAN WARNA}

Warna (bahagian kepala sampel) diukur dengan menggunakan kolorimeter dengan sistem L* (kecerahan), $a^{*}$ (kemerahan) dan b* (kekuningan) (McGuire 1992).
PENENTUAN KEHILANGAN BERAT SAMPEL

Kehilangan berat (physiological lost in weight, PLW) dihitung sebagai perbezaan berat awal dan berat pada titik masa pengukuran (24, 96 dan 168 jam), dinyatakan sebagai \% (berat awal).

\section{PENENTUAN KANDUNGAN KELEMBAPAN}

Kandungan kelembapan ditentukan dengan kaedah ketuhar (kaedah piawai penentuan kelembapan makanan) (AOAC 1990).

\section{PENENTUAN KANDUNGAN KLOROFIL}

Kandungan klorofil ditentukan dengan kaedah DMSO (Hiscox \& Israelstam 1979). Sebanyak $0.1 \mathrm{~g}$ sampel diletakkan dalam tabung uji mengandungi $10 \mathrm{~mL}$ DMSO, dipindahkan ke water bath (suhu $60{ }^{\circ} \mathrm{C}-65^{\circ} \mathrm{C}$ ) selama 1 jam, kemudian disejukkan pada suhu bilik selama 30 minit. Nilai absorbans (665 nm dan $648 \mathrm{~nm}$ ) direkodkan dan kandungan klorofil dihitung:

Kandungan klorofil $(\mathrm{mg} / \mathrm{g})=(7.49 \times$ nilai absorbans pada $665 \mathrm{~nm})+(20.34 \times$ nilai absorbans pada $648 \mathrm{~nm})$

\section{PENENTUAN AKTIVITI ANTIOKSIDA}

PENENTUAN JUMLAH KANDUNGAN FENOL (TPC)

Kandungan jumlah polifenol (TPC) ditentukan menggunakan reagen Fiolin Ciocalteu (Chew et al. 2008). Sebanyak $10 \mathrm{~g}$ sampel dicampur $50 \mathrm{~mL}$ metanol mengandungi $0.01 \% \mathrm{HCl}$. Sampel dipindahkan ke $100 \mathrm{~mL}$ kelalang volumetri dan diisi dengan asid metafosforik-asid asetik sehingga $100 \mathrm{~mL}$. Sebanyak $1 \mathrm{~mL}$ alikuot dicampur $5 \mathrm{~mL}$ reagen Fiolin Ciocalteu. Selepas 8 minit, $4 \mathrm{~mL} \mathrm{7.5 \%} \mathrm{larutan} \mathrm{natrium} \mathrm{karbonat} \mathrm{ditambah.}$ Tiub ditutup dan diletakkan dalam gelap selama 2 jam pada suhu bilik. Penyerapan pada $765 \mathrm{~nm}$ diukur. Larutan asid galik digunakan sebagai larutan piawai (Othman et al. 2020; Zayapor et al. 2020).

\section{AKTIVITI PENYINGKIRAN RADIKAL BEBAS (DPPH)}

Aktiviti antioksidan diukur melalui aktiviti penyingkiran radikal bebas (DPPH) (Chan et al. 2009). Sejumlah $300 \mu \mathrm{L}$ larutan sampel (disediakan daripada $10 \mathrm{~g}$ sampel dicampur $50 \mathrm{~mL}$ metanol $0.01 \% \mathrm{HCl}$ ), piawai dan pengosong dipipet ke dalam tiub Eppendorf. Sebanyak $300 \mu \mathrm{L}$ larutan DPPH ditambah, kemudian digoncang dan dibiarkan pada suhu bilik selama 30 minit. Penyerapan diukur pada 517 nm (Ali et al. 2019a). Asid askorbik digunakan sebagai piawai antioksida (Abidin et al. 2020; Ali et al. 2019b). Lengkung piawai disediakan dengan menggunakan asid 
askorbik (1-100 mg/L). Aktiviti penyingkiran dinyatakan sebagai mg askorbik asid setara (AEAC)/g sampel.

\section{PENENTUAN KANDUNGAN VITAMIN C}

Kandungan vitamin $\mathrm{C}$ ditentukan menggunakan kaedah 2,6-dikloroindofenol titrimetric (Cunniff 1995). Sejumlah 20-25 gm sampel ditambah kepada $180 \mathrm{~mL}$ asid metafosforik-asid asetik, sebelum dipindahkan ke kelalang volumetri dan ditambah asid metafosforikasid asetik sehingga mencapai $250 \mathrm{~mL}$. Sampel ditapis, kemudian $2 \mathrm{~mL}$ tapisan dipipet ke dalam tiga kelalang kon $50 \mathrm{~mL}$ berlainan. Sampel dititrasi dengan pewarna indofenol dan isi padu diperlukan untuk mencapai 'end point' direkod.

\section{PENENTUAN KEADAAN PENYIMPANAN YANG SESUAI}

Keadaan penyimpanan yang paling sesuai ditentukan berdasarkan kehilangan yang paling minimum daripada segi warna, PLW, kandungan kelembapan, kandungan klorofil dan aktiviti antioksidan sampel pada hari ketujuh tempoh penyimpanan (168 jam).

\section{ANALISIS STATISTIK}

Data dianalisis dalam tiga replikasi, menggunakan ujian analisis varians dua hala (ANOVA) (untuk menentukan kesan dan interaksi pemboleh ubah suhu dan keadah penyimpanan) dan ujian Tukey dengan menggunakan perisian Minitab untuk menganalisis perbezaan signifikan dalam min. Perbezaan adalah signifikan pada $\mathrm{p}<0.05$.

\section{KePUtUSAn DAN PERBinCANGAN}

Keputusan ditunjukkan dalam Jadual 1 dan 2. Secara keseluruhannya, ANOVA dua hala menunjukkan suhu dan pembungkusan memberikan kesan signifikan $(\mathrm{p}<0.05)$ terhadap parameter yang dikaji dan terdapat interaksi antara kedua-dua faktor tersebut.

\section{ANALISIS FIZIKOKIMIA} WARNA

Jadual 1 menunjukkan bacaan warna $L^{*}, a^{*}$ dan $b^{*}$. Bacaan $\mathrm{L}^{*}$ brokoli menurun dalam 4 keadaan penyimpanan yang berbeza $(p<0.05)$, menunjukkan warna semakin gelap semasa penyimpanan. Pada 168 jam, brokoli yang tidak dibungkus pada $23{ }^{\circ} \mathrm{C}$ adalah paling gelap ( $\mathrm{L}^{*}=21.11$ ), diikuti yang tidak dibungkus pada $4{ }^{\circ} \mathrm{C}\left(\mathrm{L}^{*}=25.03\right)$. Brokoli dibungkus mengalami penurunan $\mathrm{L}^{*}$ yang lebih sedikit berbanding tidak dibungkus. Warna brokoli yang tidak dibungkus bertukar kepada warna yang lebih gelap berbanding yang dibungkus. Brokoli yang tidak dibungkus mengalami kehilangan warna hijau akibat kehadiran pigmen kuning. Ini dikaitkan dengan aktiviti enzim peroksidase dan lipoksigenase (Orak 2006) dan degradasi klorofil yang mengurangkan keamatan warna hijau (Manolopoulou \& Varzakas 2016).

Brokoli pada suhu penyimpanan $4{ }^{\circ} \mathrm{C}$ mengalami penurunan $\mathrm{L}^{*}$ yang lebih sedikit berbanding pada 23 ${ }^{\circ} \mathrm{C}$. Brokoli yang disimpan pada suhu lebih rendah dapat mengekalkan warna kehijauannya berbanding pada suhu tinggi. Pramanik et al. (2004) menunjukkan brokoli yang disimpan pada suhu rendah dan dibungkus mengalami penurunan $\mathrm{L}^{*}$ yang lebih minimum berbanding dengan brokoli yang tidak dibungkus.

Nilai a* bagi brokoli dalam keadaan penyimpan yang berbeza sepanjang tempoh penyimpanan menunjukkan perbezaan yang signifikan $(\mathrm{p}<0.05)$. Nilai $\mathrm{a}^{*}$ merupakan penunjuk yang menggambarkan warna daripada kehijauan kepada kemerahan. Kesemua sampel menunjukkan ciri kehijauan pada tempoh 24 jam. Hal ini disebabkan brokoli adalah berwarna hijau pada hari pertama penyimpanan. Brokoli mengalami penurunan bacaan a* sepanjang tempoh penyimpanan, menunjukkan penurunan warna hijau (Spokowski 2010). Pada 168 jam, brokoli yang dibungkus pada $4{ }^{\circ} \mathrm{C}$ mempunyai nilai a* yang paling negatif (-9.88), diikuti dengan yang dibungkus pada $23{ }^{\circ} \mathrm{C}(-5.06)$, yang tidak dibungkus pada $4{ }^{\circ} \mathrm{C}(-3.00)$ dan akhirnya yang tidak dibungkus pada $23{ }^{\circ} \mathrm{C}(-0.06)$. Sampel brokoli yang dibungkus dan disimpan pada $4{ }^{\circ} \mathrm{C}$ mengalami kehilangan nilai a* yang paling minimum berbanding keadaan penyimpanan yang lain. Berdasarkan Jones et al. (2006), pengekalan terbaik warna hijau pada brokoli dapat diperoleh apabila brokoli disimpan dalam keadaan 1-2\% oksigen digabungkan dengan 5-10\% karbon dioksida dan disimpan pada suhu penyimpanan $0{ }^{\circ} \mathrm{C}-5^{\circ} \mathrm{C}$. Warna brokoli dapat dikekalkan dengan lebih baik dalam keadaan apabila kandungan oksigen yang rendah bergabung dengan kandungan karbon dioksida yang lebih tinggi. Hal ini menunjukkan kadar penukaran warna pada brokoli bergantung kepada tenaga yang dibekalkan semasa pertukaran gas oksigen dan karbon dioksida (Hertog et al. 2001).

Seterusnya, bacaan $b^{*}$ merupakan penunjuk bagi warna kuning. Proses kekuningan pada sayuran dapat dikawal dengan mengawal suhu penyimpanan dan jenis pembungkusan (Pankaj et al. 2011). Nilai b* paling tinggi pada 168 jam (36.55) bagi sampel brokoli yang tidak dibungkus pada $23{ }^{\circ} \mathrm{C}$, diikuti yang dibungkus pada $23{ }^{\circ} \mathrm{C}$ (34.32), yang tidak dibungkus pada $4{ }^{\circ} \mathrm{C}(21.62)$ dan yang dibungkus pada $4{ }^{\circ} \mathrm{C}$ (19.96). Sampel brokoli 
yang dibungkus mengalami peningkatan $b^{*}$ paling minimum, menunjukkan keadaan penyimpanan ini paling dapat mengekalkan warna asal brokoli. Pembungkusan dapat melambatkan perubahan warna pada brokoli disebabkan oleh peningkatan kelembapan dan perbezaan komposisi atmosfera dalam beg plastik polietilena (Rao \& Shivashankara 2015).

Keputusan menunjukkan perbezaan yang signifikan $(\mathrm{p}<0.05)$ terhadap nilai $\mathrm{L}^{*}, \mathrm{a}^{*}$ dan $\mathrm{b}^{*}$ pada bunga kobis (Jadual 1). Bacaan $L^{*}$ menurun dalam 4 keadaan penyimpanan yang berbeza. Pada 168 jam, bunga kobis yang dibungkus pada $4{ }^{\circ} \mathrm{C}$ mengalami penurunan nilai $\mathrm{L} *$ yang paling minimum (76.97 ke 67.63), manakala yang tidak dibungkus pada $23{ }^{\circ} \mathrm{C}$ mengalami penurunan nilai L* yang paling maksimum (62.74 ke 42.27). Pada 168 jam, bunga kobis yang tidak dibungkus pada $23{ }^{\circ} \mathrm{C}$ adalah paling gelap (nilai $\mathrm{L}^{*}=42.27$ ), diikuti yang dibungkus pada $23{ }^{\circ} \mathrm{C}$ (nilai $\mathrm{L}^{*}=52.17$ ).

Pada 168 jam, bunga kobis yang dibungkus pada 4 ${ }^{\circ} \mathrm{C}$ mempunyai nilai a* yang paling negatif $(-1.36)$, diikuti yang tidak dibungkus pada $4{ }^{\circ} \mathrm{C}(-0.95)$, yang dibungkus pada $23{ }^{\circ} \mathrm{C}(-0.54)$ dan akhirnya yang tidak dibungkus pada $23{ }^{\circ} \mathrm{C}(1.26)$. Bunga kobis yang dibungkus pada 4 ${ }^{\circ} \mathrm{C}$ mengalami kehilangan nilai a* yang paling minimum berbanding keadaan penyimpanan yang lain.

Nilai $b^{*}$ sampel bunga kobis pada 24 jam pertama ialah 2.36 bagi yang tidak dibungkus pada $4{ }^{\circ} \mathrm{C}, 0.88$ bagi yang dibungkus pada $4{ }^{\circ} \mathrm{C}, 4.53$ bagi yang tidak dibungkus pada $23{ }^{\circ} \mathrm{C}$ dan 5.53 bagi yang dibungkus pada $23{ }^{\circ} \mathrm{C}$. Pada 168 jam, bunga kobis yang dibungkus pada $4{ }^{\circ} \mathrm{C}$ menunjukkan nilai $b^{*}$ yang paling rendah iaitu 4.77 manakala yang dibungkus pada $23{ }^{\circ} \mathrm{C}$ menunjukkan nilai $b^{*}$ yang paling tinggi iaitu 20.55. Dengan itu, pembungkusan dengan beg plastik polietilena adalah lebih sesuai untuk penyimpanan sayur-sayuran. Sayursayuran yang dibungkus dengan beg plastik polietilena dapat memanjangkan jangka hayat simpanan (Cho et al. 2009).

\section{KEHILANGAN BERAT (PLW)}

Terdapat perbezaan yang signifikan $(\mathrm{p}<0.05)$ terhadap PLW sampel brokoli pada hari ketujuh (168 jam) tempoh penyimpanan (Jadual 1). PLW meningkat secara mendadak dalam semua keadaan penyimpanan yang berbeza, disebabkan berlakunya kehilangan kelembapan secara berterusan akibat transpirasi dan respirasi (Nath et al. 2015). Pada jam ke 168, PLW sampel yang paling maksima berlaku pada brokoli yang tidak dibungkus pada $23{ }^{\circ} \mathrm{C}(79.14 \%)$, diikuti dengan yang tidak dibungkus pada $4{ }^{\circ} \mathrm{C}(60.49 \%)$ dan yang dibungkus pada $23{ }^{\circ} \mathrm{C}$
(14.11\%). PLW sampel yang paling minimum adalah pada brokoli yang dibungkus pada $4{ }^{\circ} \mathrm{C}(2.03 \%)$.

ANOVA menunjukkan perbezaan signifikan antara pembungkusan dalam sampel brokoli $(\mathrm{p}<0.05)$. Sampel brokoli yang dibungkus pada $4{ }^{\circ} \mathrm{C}$ dan $23^{\circ} \mathrm{C}$ menunjukkan perbezaan signifikan dengan yang tidak dibungkus pada $4{ }^{\circ} \mathrm{C}$ dan $23{ }^{\circ} \mathrm{C}$. Brokoli yang dibungkus dengan beg plastik polietilena mempunyai PLW yang lebih minimum berbanding dengan yang tidak dibungkus.

Terdapat perbezaan signifikan $(\mathrm{p}<0.05)$ terhadap PLW sampel bunga kobis sepanjang tempoh penyimpanan (Jadual 1). PLW semakin meningkat sepanjang tempoh itu. Pada hari pertama, PLW bunga kobis yang tidak dibungkus pada $4{ }^{\circ} \mathrm{C}$ ialah $6.25 \%, 0.70 \%$ bagi yang dibungkus pada $4{ }^{\circ} \mathrm{C}, 38.62 \%$ bagi yang tidak dibungkus pada $23{ }^{\circ} \mathrm{C}$ dan $2.93 \%$ bagi yang dibungkus pada $23{ }^{\circ} \mathrm{C}$. Pada 168 jam, PLW paling maksima berlaku pada bunga kobis yang tidak dibungkus pada $23{ }^{\circ} \mathrm{C}(65.51 \%)$, manakala PLW sampel paling minimum adalah yang dibungkus pada $4{ }^{\circ} \mathrm{C}(0.97 \%)$.

Sayuran yang tidak dibungkus mengalami PLW yang lebih banyak berbanding yang dibungkus (Fernández-León et al. 2013). Keadaan sebegini berlaku disebabkan sayur-sayuran yang dibungkus mengalami kekurangan oksigen untuk proses respirasi dan seterusnya menurunkan kadar berlakunya respirasi. Penurunan kadar proses respirasi mengelakkan kehilangan kelembapan yang berlaku disebabkan oleh proses transpirasi (Nath et al. 2015).

\section{KANDUNGAN KELEMBAPAN}

Terdapat perbezaan signifikan $(\mathrm{p}<0.05)$ kandungan kelembapan brokoli sepanjang tempoh penyimpanan (Jadual 1). Kandungan kelembapan tertinggi pada 24 jam adalah $87.57 \%$ (tidak dibungkus pada $4{ }^{\circ} \mathrm{C}$ ) dan terendah $52.54 \%$ (tidak dibungkus pada $23{ }^{\circ} \mathrm{C}$ ) pada 168 jam. Kandungan kelembapan brokoli mula menurun pada 96 jam. Brokoli yang dibungkus mempunyai kandungan kelembapan yang lebih tinggi pada hari ketujuh iaitu $84.42 \%\left(4{ }^{\circ} \mathrm{C}\right)$ dan $71.12 \%\left(23{ }^{\circ} \mathrm{C}\right)$, berbanding dengan yang tidak dibungkus iaitu $83.40 \%\left(4{ }^{\circ} \mathrm{C}\right)$ dan $52.54 \%$ $\left(23^{\circ} \mathrm{C}\right)$. Pembungkusan brokoli dengan beg plastik polietilena merupakan kaedah penyimpanan yang baik kerana dapat mengekalkan kandungan kelembapan. Beg plastik, kotak berjajar dan tin logam merupakan bahan yang dapat mengekalkan kandungan kelembapan pada sayur-sayuran (Arvanitoyannis 2012). Li et al. (2018) mendapati suhu penyimpanan berkadar songsang dengan kelembapan. Dalam kajian ini, brokoli disimpan pada suhu $4{ }^{\circ} \mathrm{C}$ mempunyai kandungan kelembapan lebih tinggi berbanding pada suhu $23^{\circ} \mathrm{C}$. 
Kandungan kelembapan bunga kobis juga berbeza secara signifikan $(\mathrm{p}<0.05)$ sepanjang tempoh penyimpanan (Jadual 1). Bunga kobis yang segar mempunyai kandungan air sebanyak $92-94 \%$ dan dapat disimpan selama 2-4 minggu pada suhu penyimpanan $0{ }^{\circ} \mathrm{C}$ (Mudgal \& Pandey 2007). Kandungan kelembapan bunga kobis mengalami penurunan yang sedikit sepanjang tempoh penyimpanan iaitu dari $93.84 \%$ pada 24 jam kepada $90.44 \%$ pada 168 jam. Hong et al. (2002) menunjukkan bahawa kandungan kelembapan dipengaruhi oleh faktor suhu udara dan kelembapan relatif. Semakin tinggi suhu, semakin rendah kandungan kelembapan pada sayur-sayuran.

Bunga kobis yang dibungkus dan tidak dibungkus pada $4{ }^{\circ} \mathrm{C}$ menunjukkan perbezaan signifikan dengan sampel yang dibungkus dan tidak dibungkus pada $23{ }^{\circ} \mathrm{C}$. Pada 168 jam, bunga kobis yang dibungkus pada $4{ }^{\circ} \mathrm{C}$ mengandungi kelembapan paling tinggi (93.26\%), manakala yang tidak dibungkus pada $23{ }^{\circ} \mathrm{C}$ mengandungi kelembapan paling rendah (90.44\%). Pembungkusan menggunakan beg plastik polietilena dapat mengekalkan kandungan kelembapan sayursayuran. Walau bagaimanapun, kajian oleh Dhall et al. (2010) menyatakan bahawa kandungan kelembapan yang berlebihan akan terkumpul pada bunga kobis yang dibungkus. Keadaan penyimpanan sebegini menggalakkan pertumbuhan mikroorganisma dan akan menjejaskan kualiti dan merosakkan bunga kobis.

Kelembapan diperhatikan tinggi dan stabil terutamanya untuk bunga kobis bagi semua keadaan penyimpanan. Kajian Habeeb Rahman (2011) untuk tempoh yang lebih panjang ( 3 minggu) juga menunjukkan pemerhatian serupa. Namun begitu, nilai bagi setiap titik masa menunjukkan tren penurunan sepanjang penyimpanan.

\section{KANDUNGAN KLOROFIL}

Terdapat perbezaan yang signifikan $(\mathrm{p}<0.05)$ bagi kandungan klorofil sampel brokoli semasa tempoh penyimpanan (Jadual 2). Kandungan klorofil menurun bagi yang dibungkus dan meningkat bagi yang tidak dibungkus. Kandungan bagi yang dibungkus pada 4 ${ }^{\circ} \mathrm{C}$ dan $23{ }^{\circ} \mathrm{C}$ menurun dari $3.19 \mathrm{mg} / \mathrm{g}$ dan $2.90 \mathrm{mg} / \mathrm{g}$ pada 24 jam ke $2.66 \mathrm{mg} / \mathrm{g}$ dan $2.23 \mathrm{mg} / \mathrm{g}$ pada $168 \mathrm{jam}$. Degradasi berlaku semasa penyimpanan disebabkan oleh aktiviti enzim degradasi klorofil klorofilase dan peroksida (Kaewsuksaeng et al 2007). Menurut Shi et al. (2014), suhu penyimpanan merupakan faktor penurunan kandungan klorofil. Sampel brokoli pada suhu $4{ }^{\circ} \mathrm{C}$ mengalami kehilangan yang lebih minimum berbanding pada suhu $23^{\circ} \mathrm{C}$.
Di samping itu, kandungan klorofil bagi sampel brokoli yang tidak dibungkus pada $4{ }^{\circ} \mathrm{C}$ dan $23{ }^{\circ} \mathrm{C}$ meningkat daripada $3.11 \mathrm{mg} / \mathrm{g}$ dan $2.63 \mathrm{mg} / \mathrm{g}$ pada $24 \mathrm{jam}$ kepada $4.04 \mathrm{mg} / \mathrm{g}$ dan $2.82 \mathrm{mg} / \mathrm{g}$ pada $168 \mathrm{jam}$. Ini sukar untuk dijelaskan, namun satu kajian lama oleh Martin dan Sheppard (1983) mendapati klorofil meningkat semasa penyimpanan tanpa pembungkusan, dikaitkan dengan pembebasan sinaran aktif secara fotosintesis.

Jadual 2 menunjukkan tiada perbezaan signifikan ( $>0.05)$ kandungan klorofil antara sampel bunga kobis yang tidak dibungkus disimpan pada $4{ }^{\circ} \mathrm{C}$ dan $23{ }^{\circ} \mathrm{C}$ dan juga sampel bunga kobis yang dibungkus pada $4{ }^{\circ} \mathrm{C}$ pada 168 jam. Bunga kobis yang tidak dibungkus pada $4{ }^{\circ} \mathrm{C}$ kehilangan klorofil yang paling minimum pada 168 jam (25\%), manakala yang dibungkus pada $23{ }^{\circ} \mathrm{C}$ mengalami kehilangan paling maksima pada 168 jam (43\%).

Bunga kobis pada suhu $4{ }^{\circ} \mathrm{C}$ kehilangan klorofil yang lebih minimum berbanding pada suhu $23^{\circ} \mathrm{C}$. Walau bagaimanapun, tiada perbezaan yang signifikan $(\mathrm{p}>0.05)$ antara keempat-empat keadaan penyimpanan pada 96 jam. Menurut Ferrante dan Maggiore (2007), suhu penyimpanan merupakan faktor berlakunya penurunan klorofil. Mereka mengkaji salad valeriana yang disimpan pada suhu $4{ }^{\circ} \mathrm{C}$ dan $10{ }^{\circ} \mathrm{C}$. Pada hari kelima, penurunan kandungan klorofil hanya berlaku pada suhu simpanan 10 ${ }^{\circ} \mathrm{C}$. Pada hari kelapan, barulah penurunan berlaku pada suhu simpanan $4{ }^{\circ} \mathrm{C}$. Yahia et al. (2007) mencadangkan perkaitan langsung suhu dan degradasi klorofil adalah disebabkan suhu yang lebih rendah memberi kesan perencatan yang lebih besar terhadap tindak balas yang menukarkan klorofil.

\section{KANDUNGAN JUMLAH FENOL (TPC)}

Jadual 2 menunjukkan kandungan jumlah fenol (TPC) bagi sampel brokoli dalam empat keadaan penyimpanan yang berbeza sepanjang tempoh penyimpanan. Terdapat perbezaan signifikan $(\mathrm{p}<0.05)$ TPC semasa tempoh penyimpanan. TPC bagi sampel brokoli adalah dalam lingkungan $240-285 \mathrm{mg} / 100 \mathrm{~g}$ pada hari pertama. Nilai ini adalah selaras dengan kajian Gawlik-Dziki (2008) yang menyatakan bahawa TPC bagi brokoli ialah 270 $\mathrm{mg} / 100 \mathrm{~g}$.

TPC bagi brokoli dalam semua keadaan penyimpanan yang berbeza mengalami penurunan yang jelas. Brokoli yang tidak dibungkus pada $4{ }^{\circ} \mathrm{C}$ mengalami penurunan paling maksima $(239.90 \mathrm{mg} / 100 \mathrm{~g}$ kepada $77.77 \mathrm{mg} / 100$ g), manakala yang dibungkus pada $23{ }^{\circ} \mathrm{C}$ mengalami penurunan paling minimum $(284.59 \mathrm{mg} / 100 \mathrm{~g}$ kepada $171.15 \mathrm{mg} / 100 \mathrm{~g})$. Pada $168 \mathrm{jam}$, TPC bagi brokoli yang tidak dibungkus pada $4{ }^{\circ} \mathrm{C}(77.77 \mathrm{mg} / 100 \mathrm{~g})$ adalah 
paling kurang berbanding dengan yang dibungkus pada $4{ }^{\circ} \mathrm{C}(91.07 \mathrm{mg} / 100 \mathrm{~g})$, yang tidak dibungkus pada $23{ }^{\circ} \mathrm{C}$ (119.33 mg/100 g) dan juga yang dibungkus pada $23{ }^{\circ} \mathrm{C}$ $(171.15 \mathrm{mg} / 100 \mathrm{~g})$.

TPC bagi brokoli yang dibungkus lebih tinggi berbanding dengan tidak dibungkus. Ini menunjukkan kepentingan pembungkusan dalam mengekalkan kandungan fenol semasa penyimpanan. Kevers et al. (2007) dan Serrano et al. (2006) juga menyatakan bahawa jenis pembungkusan mempengaruhi kandungan fenol dalam brokoli. Ini disebabkan apabila dibungkus, kandungan oksigen adalah terhad. Tindak balas antara oksigen dengan radikal bebas berkurang dan kemungkinan berlakunya proses pengoksidaan juga akan berkurang. Dengan itu, sayur-sayuran yang dibungkus mempunyai TPC yang lebih tinggi berbanding yang tidak dibungkus.

Di samping itu, TPC bagi brokoli pada $23{ }^{\circ} \mathrm{C}$ adalah lebih tinggi berbanding pada $4^{\circ} \mathrm{C}$. Suhu penyimpanan yang tinggi mungkin mengganggu struktur sel membran dan menyebabkan berlakunya pelepasan bahan fitokimia seperti fenol (Jiménez-Monreal et al. 2009). Menurut Blessington et al. (2010), suhu yang tinggi melembutkan tisu sayur-sayuran dan membantu pengekstrakan daripada matrik sel.

Terdapat perbezaan signifikan $(\mathrm{p}<0.05)$ TPC sampel bunga kobis semasa tempoh penyimpanan (Jadual 2). TPC adalah dalam lingkungan 175-191 mg/100 g pada hari pertama. Nilai ini adalah lebih tinggi berbanding dengan kajian oleh $\mathrm{Gu}$ et al. (2015) (153 mg/100 g). TPC bunga kobis mengalami penurunan yang signifikan semasa penyimpanan. Bunga kobis mengalami penurunan yang signifikan iaitu dari $191.45 \mathrm{mg} / 100 \mathrm{~g}$ pada $24 \mathrm{jam}$ kepada $143.89 \mathrm{mg} / 100 \mathrm{~g}$ pada $168 \mathrm{jam}$. TPC bunga kobis mula menurun pada hari keempat (96 jam).

Bunga kobis yang dibungkus pada $23^{\circ} \mathrm{C}$ mengalami penurunan TPC paling minimum $(191.45 \mathrm{mg} / 100 \mathrm{~g}$ kepada $167.64 \mathrm{mg} / 100 \mathrm{~g}$ ), manakala paling maksima pada yang tidak dibungkus pada $23{ }^{\circ} \mathrm{C}(180.20 \mathrm{mg} / 100 \mathrm{~g}$ kepada $115.51 \mathrm{mg} / 100 \mathrm{~g})$. TPC bunga kobis dibungkus lebih tinggi berbanding tidak dibungkus. Ini selari dengan kajian Costa et al. (2005) terhadap perubahan kualiti brokoli yang disimpan pada $20^{\circ} \mathrm{C}$. TPC lebih tinggi bagi sampel dibungkus disebabkan oleh oksigen atmosfera yang terhad dalam pembungkusan.

\section{AKTIVITI PENYINGKIRAN RADIKAL BEBAS (DPPH)}

ANOVA menunjukkan perbezaan yang signifikan $(\mathrm{p}<0.05)$ terhadap aktiviti penyingkiran radikal bebas (DPPH) bagi sampel brokoli sepanjang tempoh penyimpanan (Jadual 2). Menurut Galani et al. (2017), penurunan aktiviti antioksida semasa penyimpanan akan membawa kepada penurunan dalam TPC, asid fenol, vitamin $\mathrm{C}$, antosianin dan karotenoid. Penurunan aktiviti penyingkiran radikal bebas dalam sampel brokoli telah berlaku sepanjang tempoh penyimpanan.

Pada 24 jam, aktiviti penyingkiran radikal bebas dalam brokoli yang tidak dibungkus pada $4{ }^{\circ} \mathrm{C}$ ialah $80.22 \%, 82.39 \%$ bagi yang dibungkus pada $4{ }^{\circ} \mathrm{C}, 80.55 \%$ bagi yang tidak dibungkus pada $23{ }^{\circ} \mathrm{C}$ dan $83.59 \%$ bagi yang dibungkus pada $23{ }^{\circ} \mathrm{C}$. Pada 168 jam, penurunan aktiviti penyingkiran radikal bebas yang paling maksima berlaku pada brokoli yang tidak dibungkus pada $4{ }^{\circ} \mathrm{C}$ (dari $80.22 \%$ kepada $69.71 \%$ ), manakala penurunan paling minimum berlaku pada sampel yang dibungkus pada $23{ }^{\circ} \mathrm{C}$ iaitu dari $83.59 \%$ kepada $77.66 \%$.

Terdapat perbezaan signifikan $(\mathrm{p}<0.05)$ terhadap aktiviti penyingkiran radikal bebas bagi sampel bunga kobis sepanjang tempoh penyimpanan (Jadual 2). Penurunan aktiviti penyingkiran radikal bebas berlaku sepanjang penyimpanan. Pada 168 jam, aktiviti penyingkiran radikal bebas bunga kobis yang dibungkus pada $23{ }^{\circ} \mathrm{C}$ adalah tertinggi $(85.51 \%)$ diikuti dengan yang tidak dibungkus pada $23{ }^{\circ} \mathrm{C}(85.39 \%)$, yang dibungkus pada $4{ }^{\circ} \mathrm{C}(84.51 \%)$ dan yang tidak dibungkus pada $4{ }^{\circ} \mathrm{C}(83.55 \%)$.

Penurunan disebabkan oleh pencairan komponen antioksidan berlaku dengan peningkatan kelembapan. Camire et al. (2005) membuktikan bahawa jagung mengalami penurunan aktiviti penyingkiran radikal bebas sepanjang tempoh penyimpanan. Kajian Walkowiak-Tomczak (2007) juga melaporkan bahawa aktiviti antioksidan dalam sampel jus chokeberi menurun semasa tempoh penyimpanan.

\section{KANDUNGAN VITAMIN C}

Terdapat perbezaan yang signifikan $(\mathrm{p}<0.05)$ pada kandungan vitamin $\mathrm{C}$ brokoli sepanjang tempoh penyimpanan (Jadual 2). Kandungan vitamin $\mathrm{C}$ tertinggi pada titik masa 24 jam adalah $130.02 \mathrm{mg} / 100 \mathrm{~g}$ (dibungkus pada $4{ }^{\circ} \mathrm{C}$ ) dan terendah pada 168 jam bagi sampel yang tidak dibungkus pada $23^{\circ} \mathrm{C}(35.31 \mathrm{mg} / 100 \mathrm{~g})$. Pada 168 jam, penurunan paling maksima berlaku pada brokoli yang tidak dibungkus pada $23{ }^{\circ} \mathrm{C}(96.24 \mathrm{mg} / 100$ g kepada $35.31 \mathrm{mg} / 100 \mathrm{~g}$ ), manakala paling minimum berlaku pada yang dibungkus pada $4{ }^{\circ} \mathrm{C}(130.02 \mathrm{mg} / 100$ g kepada $122.05 \mathrm{mg} / 100 \mathrm{~g}$ ).

Brokoli yang dibungkus mengandungi vitamin $\mathrm{C}$ lebih tinggi berbanding tidak dibungkus. Menurut Rai et al. (2008), pembungkusan penting untuk mengekalkan kandungan vitamin $\mathrm{C}$ semasa penyimpanan. Kandungan vitamin $\mathrm{C}$ yang tinggi dalam brokoli dibungkus disebabkan oleh oksigen atmosfera yang terhad untuk proses pengoksidaan. 
Terdapat perbezaan yang signifikan $(\mathrm{p}<0.05)$ pada bunga kobis sepanjang tempoh penyimpanan (Jadual 2). Penurunan kandungan vitamin $C$ berlaku sepanjang tempoh penyimpanan. Pada $168 \mathrm{jam}$, kandungan vitamin $\mathrm{C}$ bagi bunga kobis yang dibungkus pada $4{ }^{\circ} \mathrm{C}$ adalah tertinggi (41.92 mg/100 g), diikuti dengan yang tidak dibungkus pada $4{ }^{\circ} \mathrm{C}(40.82 \mathrm{mg} / 100 \mathrm{~g})$, dibungkus pada $23^{\circ} \mathrm{C}(37.06 \mathrm{mg} / 100 \mathrm{~g})$ dan yang tidak dibungkus pada $23^{\circ} \mathrm{C}(23.65 \mathrm{mg} / 100 \mathrm{~g})$.

Suhu merupakan faktor utama yang mempengaruhi kandungan vitamin $\mathrm{C}$ pada sayur-sayuran. Bunga kobis yang disimpan pada suhu $4{ }^{\circ} \mathrm{C}$ mengalami penurunan kandungan vitamin $\mathrm{C}$ yang lebih minimum berbanding yang disimpan pada suhu $23{ }^{\circ} \mathrm{C}$. Sayur-sayuran yang disimpan pada suhu $15{ }^{\circ} \mathrm{C}$ dan ke atas akan mengalami degradasi vitamin $C$ yang sangat cepat (Leja et al. 2011). Menurut Frankee et al. (2004), vitamin C merupakan nutrien yang paling tidak stabil dan sensitif kepada suhu dan proses pengoksidan. Degradasi vitamin C mula berlaku selepas proses penuaian sayur-sayuran degradasi berlaku secara berterusan sepanjang tempoh penyimpanan (Rickman et al. 2007).

JADUAL 1. Bacaan warna L*, a* dan b*, kehilangan berat (PLW) dan kandungan kelembapan bagi sampel brokoli dan bunga kobis

\begin{tabular}{|c|c|c|c|c|c|c|}
\hline \multirow{2}{*}{ Jam } & \multirow{2}{*}{ Keadaan penyimpanan } & \multicolumn{3}{|c|}{ Bacaan purata warna } & \multirow{2}{*}{$\begin{array}{c}\text { Kehilangan } \\
\text { berat } \\
(\%)\end{array}$} & \multirow{2}{*}{$\begin{array}{c}\text { Kandungan } \\
\text { kelembapan } \\
(\%)\end{array}$} \\
\hline & & $\mathrm{L}^{*}$ & $a^{*}$ & $b^{*}$ & & \\
\hline \multicolumn{7}{|l|}{$\underline{\text { Brokoli }}$} \\
\hline \multirow[t]{4}{*}{24} & Tidak dibungkus $/ 4^{\circ} \mathrm{C}$ & $33.78 \pm 0.02^{\mathrm{c}}$ & $-9.98 \pm 0.01^{\mathrm{b}}$ & $17.63 \pm 0.01^{\mathrm{b}}$ & $35.50 \pm 0.05^{\mathrm{a}}$ & $87.57 \pm 0.15^{\mathrm{a}}$ \\
\hline & Dibungkus $/ 4{ }^{\circ} \mathrm{C}$ & $47.32 \pm 0.00^{\mathrm{a}}$ & $-12.51 \pm 0.00^{\mathrm{d}}$ & $16.56 \pm 0.03^{\mathrm{d}}$ & $1.01 \pm 0.21^{\mathrm{b}}$ & $87.51 \pm 0.04^{\mathrm{a}}$ \\
\hline & Tidak dibungkus $/ 23^{\circ} \mathrm{C}$ & $31.62 \pm 0.02^{\mathrm{d}}$ & $-9.13 \pm 0.10^{\mathrm{a}}$ & $18.63 \pm 0.15^{\mathrm{a}}$ & $40.19 \pm 3.47^{\mathrm{a}}$ & $85.13 \pm 0.06^{\mathrm{b}}$ \\
\hline & Dibungkus $/ 23{ }^{\circ} \mathrm{C}$ & $37.44 \pm 0.18^{b}$ & $-10.78 \pm 0.01^{\mathrm{c}}$ & $16.87 \pm 0.02^{\mathrm{c}}$ & $3.70 \pm 0.55^{\mathrm{b}}$ & $85.13 \pm 0.06^{\mathrm{b}}$ \\
\hline \multirow[t]{4}{*}{96} & Tidak dibungkus $/ 4^{\circ} \mathrm{C}$ & $27.63 \pm 0.06^{c}$ & $-7.08 \pm 0.01^{b}$ & $19.96 \pm 0.03^{c}$ & $55.09 \pm 0.92^{\mathrm{a}}$ & $84.64 \pm 0.88^{\mathrm{ab}}$ \\
\hline & Dibungkus $/ 4{ }^{\circ} \mathrm{C}$ & $40.68 \pm 0.00^{\mathrm{a}}$ & $-10.36 \pm 0.02^{\mathrm{d}}$ & $17.07 \pm 0.02^{\mathrm{d}}$ & $1.80 \pm 0.24^{\mathrm{b}}$ & $85.48 \pm 0.03^{\mathrm{a}}$ \\
\hline & Tidak dibungkus $/ 23^{\circ} \mathrm{C}$ & $27.21 \pm 0.03^{\mathrm{d}}$ & $-6.28 \pm 0.12^{\mathrm{a}}$ & $23.97 \pm 0.04^{\mathrm{a}}$ & $60.87 \pm 3.34^{\mathrm{a}}$ & $79.93 \pm 0.54^{\mathrm{c}}$ \\
\hline & Dibungkus $/ 23{ }^{\circ} \mathrm{C}$ & $36.56 \pm 0.01^{\mathrm{b}}$ & $-8.76 \pm 0.03^{c}$ & $21.39 \pm 0.04^{\mathrm{b}}$ & $10.80 \pm 0.22^{b}$ & $83.45 \pm 0.07^{\mathrm{b}}$ \\
\hline \multirow[t]{4}{*}{168} & Tidak dibungkus $/ 4^{\circ} \mathrm{C}$ & $25.03 \pm 0.01^{\mathrm{c}}$ & $-3.00 \pm 0.00^{b}$ & $21.62 \pm 0.00^{b}$ & $60.49 \pm 0.93^{b}$ & $83.40 \pm 0.20^{\mathrm{a}}$ \\
\hline & Dibungkus $/ 4^{\circ} \mathrm{C}$ & $40.63 \pm 0.01^{\mathrm{a}}$ & $-9.88 \pm 0.00^{\mathrm{d}}$ & $19.71 \pm 0.05^{\mathrm{d}}$ & $2.03 \pm 0.05^{\mathrm{d}}$ & $84.42 \pm 0.75^{\mathrm{a}}$ \\
\hline & Tidak dibungkus $/ 23^{\circ} \mathrm{C}$ & $21.11 \pm 0.00^{\mathrm{d}}$ & $-0.06 \pm 0.01^{\mathrm{a}}$ & $34.32 \pm 0.03^{\mathrm{a}}$ & $79.14 \pm 0.99^{\mathrm{a}}$ & $52.54 \pm 0.47^{\mathrm{c}}$ \\
\hline & Dibungkus $/ 23^{\circ} \mathrm{C}$ & $30.13 \pm 0.02^{\mathrm{b}}$ & $-5.06 \pm 0.00^{c}$ & $36.55 \pm 0.13^{\mathrm{c}}$ & $14.11 \pm 1.22^{\mathrm{c}}$ & $71.12 \pm 1.37^{\mathrm{b}}$ \\
\hline \multicolumn{7}{|c|}{$\underline{\text { Bunga kobis }}$} \\
\hline \multirow[t]{4}{*}{24} & Tidak dibungkus $/ 4^{\circ} \mathrm{C}$ & $73.26 \pm 0.00^{\mathrm{b}}$ & $-4.45 \pm 0.07^{b}$ & $2.36 \pm 0.01^{\mathrm{c}}$ & $6.25 \pm 0.67^{b}$ & $93.70 \pm 0.15^{\mathrm{a}}$ \\
\hline & Dibungkus $/ 4^{\circ} \mathrm{C}$ & $76.97 \pm 0.02^{\mathrm{a}}$ & $-5.85 \pm 0.02^{\mathrm{d}}$ & $0.88 \pm 0.01^{\mathrm{d}}$ & $0.70 \pm 0.13^{\mathrm{b}}$ & $93.84 \pm 0.00^{\mathrm{a}}$ \\
\hline & Tidak dibungkus $/ 23^{\circ} \mathrm{C}$ & $62.74 \pm 0.24^{\mathrm{d}}$ & $-3.307 \pm 0.00^{\mathrm{a}}$ & $4.53 \pm 0.06^{\mathrm{b}}$ & $38.62 \pm 13.3^{\mathrm{a}}$ & $93.15 \pm 0.06^{\mathrm{b}}$ \\
\hline & Dibungkus $/ 23{ }^{\circ} \mathrm{C}$ & $65.74 \pm 0.24^{\mathrm{c}}$ & $-4.72 \pm 0.00^{c}$ & $5.53 \pm 0.00^{\mathrm{a}}$ & $2.93 \pm 0.36^{\mathrm{b}}$ & $93.64 \pm 0.12^{\mathrm{a}}$ \\
\hline \multirow[t]{4}{*}{96} & Tidak dibungkus $/ 4{ }^{\circ} \mathrm{C}$ & $69.26 \pm 0.02^{\mathrm{b}}$ & $-1.56 \pm 0.00^{\mathrm{b}}$ & $5.36 \pm 0.00^{\mathrm{c}}$ & $7.21 \pm 0.56^{\mathrm{b}}$ & $93.36 \pm 0.09^{\mathrm{a}}$ \\
\hline & Dibungkus $/ 4^{\circ} \mathrm{C}$ & $70.54 \pm 0.02^{\mathrm{a}}$ & $-3.89 \pm 0.01^{\mathrm{d}}$ & $3.89 \pm 0.10^{\mathrm{d}}$ & $0.85 \pm 0.02^{\mathrm{b}}$ & $93.49 \pm 0.05^{\mathrm{a}}$ \\
\hline & Tidak dibungkus $/ 23^{\circ} \mathrm{C}$ & $56.77 \pm 0.02^{\mathrm{d}}$ & $-0.84 \pm 0.06^{\mathrm{a}}$ & $12.31 \pm 0.00^{\mathrm{b}}$ & $45.36 \pm 12.38^{\mathrm{a}}$ & $92.62 \pm 0.14^{\mathrm{b}}$ \\
\hline & Dibungkus $/ 23{ }^{\circ} \mathrm{C}$ & $62.41 \pm 0.00^{\mathrm{c}}$ & $-2.52 \pm 0.04^{\mathrm{c}}$ & $18.18 \pm 0.00^{\mathrm{a}}$ & $4.98 \pm 1.09^{\mathrm{b}}$ & $92.74 \pm 0.08^{\mathrm{b}}$ \\
\hline \multirow[t]{4}{*}{168} & Tidak dibungkus $/ 4^{\circ} \mathrm{C}$ & $63.15 \pm 0.01^{\mathrm{b}}$ & $-0.95 \pm 0.00^{c}$ & $8.60 \pm 0.00^{c}$ & $10.74 \pm 1.03^{b}$ & $93.02 \pm 0.10^{\mathrm{a}}$ \\
\hline & Dibungkus $/ 4{ }^{\circ} \mathrm{C}$ & $67.63 \pm 0.15^{\mathrm{a}}$ & $-1.36 \pm 0.00^{\mathrm{d}}$ & $4.77 \pm 0.00^{\mathrm{d}}$ & $0.97 \pm 0.50^{c}$ & $93.26 \pm 0.08^{\mathrm{a}}$ \\
\hline & Tidak dibungkus $/ 23^{\circ} \mathrm{C}$ & $42.27 \pm 0.06^{\mathrm{d}}$ & $1.26 \pm 0.00^{\mathrm{a}}$ & $20.55 \pm 0.01^{\mathrm{b}}$ & $65.51 \pm 2.08^{\mathrm{a}}$ & $90.44 \pm 0.48^{\mathrm{b}}$ \\
\hline & Dibungkus $/ 23{ }^{\circ} \mathrm{C}$ & $52.17 \pm 0.12^{\mathrm{c}}$ & $-0.54 \pm 0.00^{\mathrm{b}}$ & $19.77 \pm 0.33^{\mathrm{a}}$ & $8.97 \pm 1.22^{\mathrm{b}}$ & $90.98 \pm 0.01^{\mathrm{b}}$ \\
\hline
\end{tabular}

*a-d Abjad yang berlainan menunjukkan perbezaan yang signifikan pada lajur yang sama bagi setiap titik masa (p<0.05), berasingan bagi sampel brokoli dan bunga kobis. Nilai menunjukkan $\min \pm$ sisihan piawai 
JADUAL 2. Kandungan klorofil, kandungan jumlah fenol (TPC), aktiviti penyingkiran radikal bebas (DPPH), dan kandungan vitamin $\mathrm{C}$ bagi sampel brokoli dan bunga kobis

\begin{tabular}{|c|c|c|c|c|c|}
\hline Jam & Keadaan penyimpanan & $\begin{array}{l}\text { Kandungan klorofil } \\
\qquad(\mathrm{mg} / \mathrm{g})\end{array}$ & $\begin{array}{l}\text { Kandungan jumlah } \\
\text { fenol (mg / } 100 \mathrm{~g})\end{array}$ & $\begin{array}{c}\text { Aktiviti } \\
\text { penyingkiran radikal } \\
\text { bebas }(\%)\end{array}$ & $\begin{array}{l}\text { Kandungan vitamin } \\
\text { C (mg / } 100 \mathrm{~g})\end{array}$ \\
\hline \multicolumn{6}{|l|}{ Brokoli } \\
\hline \multirow{5}{*}{24} & Tidak dibungkus $/ 4^{\circ} \mathrm{C}$ & $3.11 \pm 0.01^{\mathrm{b}}$ & $239.9 \pm 0.97^{d}$ & $80.22 \pm 0.06^{c}$ & $118.03 \pm 0.18^{c}$ \\
\hline & Dibungkus $/ 4^{\circ} \mathrm{C}$ & $3.19 \pm 0.00^{\mathrm{a}}$ & $251.93 \pm 0.06^{\mathrm{b}}$ & $81.39 \pm 0.29^{b}$ & $130.02 \pm 0.05^{\mathrm{a}}$ \\
\hline & Tidak dibungkus $/ 23^{\circ} \mathrm{C}$ & $2.63 \pm 0.00^{\mathrm{d}}$ & $249.91 \pm 0.91^{c}$ & $80.55 \pm 0.04^{c}$ & $96.24 \pm 0.22^{\mathrm{d}}$ \\
\hline & Dibungkus $/ 23{ }^{\circ} \mathrm{C}$ & $2.90 \pm 0.00^{c}$ & $284.59 \pm 0.42^{\mathrm{a}}$ & $83.59 \pm 0.00^{\mathrm{a}}$ & $120.75 \pm 0.28^{\mathrm{b}}$ \\
\hline & Tidak dibungkus $/ 4{ }^{\circ} \mathrm{C}$ & $3.49 \pm 0.02^{\mathrm{a}}$ & $204.38 \pm 0.18^{d}$ & $77.53 \pm 0.00^{\mathrm{b}}$ & $113.01 \pm 0.00^{\mathrm{b}}$ \\
\hline \multirow{3}{*}{96} & Dibungkus $/ 4{ }^{\circ} \mathrm{C}$ & $2.84 \pm 0.22^{b}$ & $219.78 \pm 0.02^{b}$ & $79.63 \pm 0.20^{\mathrm{a}}$ & $128.36 \pm 0.62^{\mathrm{a}}$ \\
\hline & Tidak dibungkus $/ 23^{\circ} \mathrm{C}$ & $2.65 \pm 0.03^{b}$ & $217.04 \pm 0.01^{\mathrm{c}}$ & $79.89 \pm 0.00^{\mathrm{a}}$ & $80.01 \pm 0.2^{\mathrm{d}}$ \\
\hline & Dibungkus $/ 23^{\circ} \mathrm{C}$ & $2.59 \pm 0.05^{\mathrm{b}}$ & $225.43 \pm 0.31^{\mathrm{a}}$ & $79.89 \pm 0.03^{\mathrm{a}}$ & $103.46 \pm 0.30^{c}$ \\
\hline \multirow{4}{*}{168} & Tidak dibungkus $/ 4^{\circ} \mathrm{C}$ & $4.04 \pm 0.04^{\mathrm{a}}$ & $77.77 \pm 0.01^{\mathrm{d}}$ & $69.71 \pm 0.11^{\mathrm{d}}$ & $92.19 \pm 0.12^{\mathrm{b}}$ \\
\hline & Dibungkus $/ 4^{\circ} \mathrm{C}$ & $2.66 \pm 0.20^{\mathrm{b}}$ & $91.07 \pm 0.05^{\mathrm{c}}$ & $71.55 \pm 0.00^{c}$ & $122.05 \pm 0.07^{\mathrm{a}}$ \\
\hline & Tidak dibungkus $/ 23^{\circ} \mathrm{C}$ & $2.82 \pm 0.02^{b}$ & $119.33 \pm 0.04^{b}$ & $73.95 \pm 0.15^{\mathrm{b}}$ & $35.31 \pm 0.30^{\mathrm{d}}$ \\
\hline & Dibungkus $/ 23{ }^{\circ} \mathrm{C}$ & $2.23 \pm 0.13^{\mathrm{c}}$ & $171.15 \pm 0.11^{\mathrm{a}}$ & $77.66 \pm 0.04^{\mathrm{a}}$ & $90.15 \pm 0.13^{\mathrm{c}}$ \\
\hline \multicolumn{6}{|c|}{ Bunga kobis } \\
\hline \multirow{4}{*}{24} & Tidak dibungkus $/ 4^{\circ} \mathrm{C}$ & $1.47 \pm 0.00^{\mathrm{b}}$ & $175.70 \pm 0.00^{\mathrm{d}}$ & $87.88 \pm 0.01^{\mathrm{d}}$ & $52.31 \pm 0.06^{\mathrm{d}}$ \\
\hline & Dibungkus $/ 4^{\circ} \mathrm{C}$ & $1.49 \pm 0.01^{\mathrm{b}}$ & $177.63 \pm 0.01^{\mathrm{c}}$ & $89.55 \pm 0.00^{\mathrm{c}}$ & $57.40 \pm 0.02^{\mathrm{c}}$ \\
\hline & Tidak dibungkus $/ 23^{\circ} \mathrm{C}$ & $1.47 \pm 0.02^{\mathrm{b}}$ & $180.20 \pm 0.05^{\mathrm{b}}$ & $92.25 \pm 0.00^{\mathrm{b}}$ & $66.08 \pm 0.02^{b}$ \\
\hline & Dibungkus $/ 23{ }^{\circ} \mathrm{C}$ & $1.62 \pm 0.01^{\mathrm{a}}$ & $191.45 \pm 0.03^{\mathrm{a}}$ & $94.44 \pm 0.00^{\mathrm{a}}$ & $71.91 \pm 0.05^{\mathrm{a}}$ \\
\hline \multirow{4}{*}{96} & Tidak dibungkus $/ 4{ }^{\circ} \mathrm{C}$ & $1.31 \pm 0.21^{\mathrm{a}}$ & $164.75 \pm 0.17^{\mathrm{d}}$ & $87.30 \pm 0.00^{c}$ & $32.58 \pm 0.02^{\mathrm{d}}$ \\
\hline & Dibungkus $/ 4^{\circ} \mathrm{C}$ & $1.26 \pm 0.13^{\mathrm{a}}$ & $165.47 \pm 0.07^{\mathrm{c}}$ & $88.54 \pm 0.00^{\mathrm{b}}$ & $45.37 \pm 0.02^{\mathrm{b}}$ \\
\hline & Tidak dibungkus $/ 23^{\circ} \mathrm{C}$ & $1.25 \pm 0.05^{\mathrm{a}}$ & $176.05 \pm 0.00^{\mathrm{b}}$ & $86.18 \pm 0.01^{\mathrm{d}}$ & $36.27 \pm 0.02^{\mathrm{c}}$ \\
\hline & Dibungkus $/ 23{ }^{\circ} \mathrm{C}$ & $1.23 \pm 0.06^{\mathrm{a}}$ & $180.37 \pm 0.00^{\mathrm{a}}$ & $89.87 \pm 0.06^{\mathrm{a}}$ & $50.52 \pm 0.02^{\mathrm{a}}$ \\
\hline \multirow{4}{*}{168} & Tidak dibungkus $/ 4{ }^{\circ} \mathrm{C}$ & $1.22 \pm 0.01^{\mathrm{a}}$ & $143.89 \pm 0.06^{\mathrm{c}}$ & $83.55 \pm 0.35^{\mathrm{b}}$ & $40.82 \pm 0.01^{\mathrm{b}}$ \\
\hline & Dibungkus $/ 4{ }^{\circ} \mathrm{C}$ & $1.22 \pm 0.00^{\mathrm{a}}$ & $147.18 \pm 0.04^{b}$ & $84.51 \pm 0.00^{\mathrm{a}}$ & $41.92 \pm 0.00^{\mathrm{a}}$ \\
\hline & Tidak dibungkus $/ 23^{\circ} \mathrm{C}$ & $1.20 \pm 0.00^{\mathrm{a}}$ & $115.51 \pm 0.10^{\mathrm{d}}$ & $85.39 \pm 0.00^{\mathrm{a}}$ & $23.65 \pm 0.00^{\mathrm{d}}$ \\
\hline & Dibungkus $/ 23{ }^{\circ} \mathrm{C}$ & $1.19 \pm 0.00^{\mathrm{a}}$ & $167.64 \pm 0.08^{\mathrm{a}}$ & $85.51 \pm 0.00^{\mathrm{a}}$ & $37.06 \pm 0.04^{c}$ \\
\hline
\end{tabular}

*a-d Abjad yang berlainan menunjukkan perbezaan yang signifikan pada lajur yang sama bagi setiap titik masa ( $\mathrm{p}<0.05)$, berasingan bagi sampel brokoli dan bunga kobis. Nilai menunjukkan $\min \pm$ sisihan piawai

\section{KESIMPULAN}

Suhu penyimpanan dan kaedah pembungkusan yang berbeza mempunyai kesan ke atas perubahan kualiti fizikokimia sampel brokoli dan bunga kobis sepanjang tempoh penyimpanan selama 168 jam. Sampel brokoli dan bunga kobis yang disimpan pada suhu penyimpanan $4{ }^{\circ} \mathrm{C}$ dan dibungkus dengan beg plastik polietilena mengalami kehilangan yang paling minimum daripada segi warna, PLW, kandungan kelembapan, kandungan klorofil, antioksidan dan kandungan vitamin $\mathrm{C}$ berbanding 
dengan sampel yang disimpan pada $23{ }^{\circ} \mathrm{C}$ dan tidak dibungkus. Bagi ujian antioksidan, sampel yang dibungkus dan disimpan pada $23{ }^{\circ} \mathrm{C}$ mempunyai TPC dan aktiviti penyingkiran radikal bebas (DPPH) yang lebih tinggi berbanding dengan yang tidak dibungkus dan disimpan pada $4{ }^{\circ} \mathrm{C}$. Justeru, keadaan penyimpanan yang paling sesuai bagi sampel brokoli dan bunga kobis ialah disimpan pada suhu penyimpanan $4{ }^{\circ} \mathrm{C}$ dan dibungkus dengan beg plastik polietilena.

\section{PENGHARGAAN}

Terima kasih kepada Jabatan Sains Makanan, Fakulti Sains dan Teknologi, Universiti Kebangsaan Malaysia untuk fasiliti dalam menjalankan penyelidikan ini.

\section{RUJUKAN}

Abidin, I.Z.Z., Fazry, S., Jamar, N.H., Dyari, H.R.E., Ariffin, Z.Z., Johari, A.N., Ashaari, N.S., Johari, N.A., Wahab, R.M.A. \& Ariffin, S.H.Z. 2020. The effects of Piper sarmentosum aqueous extracts on zebrafish (Danio rerio) embryos and caudal fin tissue regeneration. Scientific Reports 10(1): 1-11.

Ali, A.A.M., Noor, H.S.M., Chong, P.K., Babji, A.S. \& Lim, S.J. 2019a. Comparison of amino acids profile and antioxidant activities between edible bird nest and chicken egg. Malaysian Applied Biology 48(2): 63-66.

Ali, S.A.M., Mohd, C.R.C. \& Latip, J. 2019b. Comparison of phenolic constituent in Hibiscus sabdariffa cv. UKMR-2 Calyx at different harvesting times. Sains Malaysiana 48(7): $1417-1424$.

AOAC. 1990. Official Methods of Analysis. Edisi ke-15. Washington D.C.: AOAC International.

Arvanitoyannis, I. 2012. Modified Atmosphere and Active Packaging Technologies. Boca Raton: CRC Press.

Bastrash, S., Makhlouf, J., Castaigne, F. \& Willemot, C. 2003. Optimal controlled atmosphere conditions for storage of broccoli florets. Journal of Food Science 58: 338-341.

Blessington, T., Nzaramba, M.N., Scheuring, D.C., Hale, A.L., Reddivari, L. \& Miller, J.C. 2010. Cooking methods and storage treatments of potato: Effects on carotenoids, antioxidant activity and phenolics. American Journal of Potato Research 87(6): 479-491.

Camire, M.E., Dougherty, M.P. \& Briggs, J.L. 2005. Antioxidantrich foods retard lipid oxidation in extruded corn. Cereal Chemistry 82(6): 666-670.

Cantwell, M.I. \& Kasmire, R.F. 2002. Handling systems: Flower, leafy, and stem vegetables, In Postharvest Technology of Horticultural Crops, disunting oleh Kander, A.A. Richmond, Calif.: Univ. California Agriculture and Natural Resources Communication Services. hlm. 423-432.

Chan, E.W.C., Lim, Y.Y., Wong, S.K., Lim, K.K., Tan, S.P. \& Lianto, F.S. 2009. Effects of different drying methods on the antioxidant properties of leaves and tea of ginger species. Food Chemistry 113: 166-172.
Chew, Y.L., Lim, Y.Y., Omar, M. \& Khoo, K.S. 2008. Antioxidant activity of three edible seaweeds from two areas in South East Asia. Journal of Food Science and Technology 41: 1067-1072.

Cho, M., Hong, Y., Choi, J., Won, Y. \& Bae, D. 2009. Effect of packaging film and storage temperature on quality maintenance of broccoli. Journal of Horticultural Science and Technology 27(1): 128-139.

Costa, M.L., Civello, P.M., Chaves, A.R. \& Martínez, G.A. 2005. Effect of hot air treatments on senescence and quality parameters of harvested broccoli heads. Journal of the Science of Food and Agriculture 85(7): 1154-1160.

Crisosto, C.H., Mitcham, B. \& Cantwell, M. 2008. Optimum temperature conditions for produce handlers. Central Valley Postharvest Newsletter 17: 1-18.

Cunniff, P. 1995. Official Methods of Analysis of AOAC International. Edisi ke-16. Arlington VA: AOAC International.

Dhall, R.K., Sharma, S.R. \& Mahajan, B.V.C. 2010. Effect of packaging on storage life and quality of cauliflower stored at low temperature. Journal of Food Science and Technology 47(1): 132-135.

Fernández-León, M.F., Fernández-León, A.M., Lozano, M., Ayuso, M.C., Amodio, M.L., Colelli, G. \& GonzálezGómez, D. 2013. Retention of quality and functional values of broccoli 'Parthenon' stored in modified atmosphere packaging. Food Control 31(2): 302-313.

Ferrante, A. \& Maggiore, T. 2007. Chlorophyll a fluorescence measurement to evaluate storage time and temperature of Valeriana leafy vegetables. Postharvest Biology and Technology 45(1): 73-80.

Franke, A.A., Custer, L.J., Arakaki, C. \& Murphy, S.P. 2004. Vitamin $\mathrm{C}$ and flavonoid levels of fruits and vegetables consumed in Hawaii. Journal of Food Composition and Analysis 17(1): 1-35.

Galani, J.H.Y., Mankad, P.M., Shah, A.K., Patel, N.J., Acharya, R.R. \& Talati, J.G. 2017. Effect of storage temperature on vitamin $\mathrm{C}$, total phenolics, UPLC phenolic acid profile and antioxidant capacity of eleven potato varieties. Horticultural Plant Journal 3(2): 73-89.

Gawlik-Dziki, U. 2008. Effect of hydrothermal treatment on the antioxidant properties of broccoli florets. Food Chemistry 109(2): 393-401.

Gu, H., Wang, J., Zhao, Z., Sheng, X., Yu, H. \& Huang, W. 2015. Characterisation of the appearance, health-promoting compounds and antioxidant capacity of the florets of the loose-curd cauliflower. International Journal of Food Properties 18(2): 392-402.

Habeeb Rahman, A. 2011. Quality aspects of cauliflower during storage. International Food Research Journal 18: 427-431.

Hertog, M.L., Nicholson, S.E. \& Banks, N.H. 2001. The effect of modified atmospheres on the rate of firmness change in 'Braeburn' apples. Postharvest Biology and Technology 23(3): 175-184.

Hiscox, J.D. \& Israelstam, G.F. 1979. A method for extraction of chlorophyll from leaf tissue without eration. Canadian Journal of Botany 57: 1332-1334. 
Hong, T.D., Ellis, R.H., Gunn, J. \& Moore, D. 2002. Relative humidity, temperature, and the equilibrium moisture content of conidia of Beauveria bassiana (Balsamo) Vuillemin: A quantitative approach. Journal of Stored Products Research 38(1): 33-41.

Jiménez-Monreal, A.M., García-Diz, L., Martínez-Tomé, M., Mariscal, M.M.M.A. \& Murcia, M.A. 2009. Influence of cooking methods on antioxidant activity of vegetables. Journal of Food Science 74(3): H97-H103.

Jones, R.B., Faragher, J.D. \& Winkler, S. 2006. A review of the influence of postharvest treatments on quality and glucosinolate content in broccoli heads. Postharvest Biology and Technology 41(1): 1-8.

Kaewsuksaeng, S., Yamauchi, N., Funamoto, Y., Mori, T., Shigyo, M. \& Kanlayanarat, S. 2007. Effect of heat treatment on catabolites formation in relation to chlorophyll degradation during storage of broccoli florets. Journal of the Japanese Society for Horticultural Science 76(4): 338-344.

Kevers, C., Falkowski, M., Tabart, J., Defraigne, J.O., Dommes, J. \& Pincemail, J. 2007. Evolution of antioxidant capacity during storage of selected fruits and vegetables. Journal of Agricultural and Food Chemistry 55(21): 8596-8603.

Leja, M., Mareczek, A., Starzynska, A. \& Rozek, S. 2011. Antioxidant ability of broccoli flower buds during short-term storage. Food Chemistry 72(2): 219-222.

Li, J., Li, Q., Lei, X., Tian, W., Cao, J., Jiang, W. \& Wang, M. 2018. Effects of wax coating on the moisture loss of cucumbers at different storage temperatures. Journal of Food Quality 2018: 1-7.

Manolopoulou, E. \& Varzakas, T. 2016. Effect of temperature in color changes of green vegetables. Current Research in Nutrition and Food Science Journal 4(Special Issue Nutrition in Conference October 2016): 10-17.

Martin, S.K. \& Sheppard, R.L. 1983. Effect of different packaging materials and light exposure times on chlorophyll concentration in 2 cultivars of potato. New Zealand Journal of Experimental Agriculture 11(1): 63-67.

McGuire, R.G. 1992. Reporting of objective colour measurements. HortScience 27: 1254-1255.

Mgaya-Kilima, B., Remberg, S.F., Chove, B.E. \& Wicklund, T. 2015. Physicochemical and antioxidant properties of rosellemango juice blends; effects of packaging materials, storage temperature and time. Food Science and Nutrition 3: 100-109.

Mudgal, V.D. \& Pandey, V.K. 2007. Dehydration characteristics of cauliflower. International Journal of Food Engineering 3(6): Article 6.

Nath, A., Mandal, S., Singh, R.K., Deka, B.C. \& Ngachan, S.V. 2015. Ascorbic acid, $\beta$-carotene and antioxidant activity of broccoli during short-term refrigerated storage. In Processing and Impact on Active Components in Food. Massachusetts: Academic Press. hlm. 27-34.

Orak, H.H. 2006. Effect of different blanching methods on peroxidase and lipoxygenase activity of broccoli and comparison of some nutritional values at enzymes inactivation levels. Acta Alimentaria 35(3): 259-268.
Othman, Z.S., Maskat, M.Y. \& Hassan, N.H. 2020. Optimization of cinnamaldehyde extraction and antioxidant activity of Ceylon cinnamon extract. Sains Malaysiana 49(5): 995-1002.

Pankaj, B.P., Umezuruike, L.O. \& Fahad, A.J.S. 2011. Colour measurement and analysis in fresh and processed foods: A review. Food and Bioprocess Technology 6(1): 36-60.

Paramithiotis, S., Hondrodimou, O.L. \& Drosinos, E.H. 2010. Development of the microbial community during spontaneous cauliflower fermentation. Food Research International 43: 1098-1103.

Podsędek, A. 2007. Natural antioxidants and antioxidant capacity of Brassica vegetables: A review. LWT-Food Science and Technology 40(1): 1-11.

Pramanik, B.K., Matsui, T., Suzuki, H. \& Kosugi, Y. 2004. Changes in acid invertase activity and sugar distribution during postharvest senescence in broccoli. Pakistan Journal of Biological Sciences 7: 679-684.

Rai, D.R., Tyagi, S.K., Jha, S.N. \& Mohan, S. 2008. Qualitative changes in the broccoli under modified atmosphere packaging in perforated polymeric film. Jounal of Food Science and Technology 45(3): 247-250.

Rao, D.S. \& Shivashankara, K.S. 2015. Individual shrink wrapping extends the storage life and maintains the antioxidants of mango stored at $8{ }^{\circ} \mathrm{C}$. Journal of Food Science and Technology 52(7): 4351-4359.

Rickman, J.C., Barrett, D.M. \& Bruhn, C.M. 2007. Nutritional comparison of fresh, frozen and canned fruits and vegetables. Journal of the Science of Food and Agriculture 87(6): 930944.

Safaryani, N., Haryanti, S. \& Hastuti, E.D. 2007. Pengaruh suhu dan lama penyimpanan terhadap penurunan kadar vitamin C brokoli. Anatomi Fisiologi 15(2): 39-45.

Serrano, M., Castillo, S., Guillen, F. \& Martinez-Romero, D. 2006. Maintenance of broccoli quality and functional properties during cold storage as affected by modified atmosphere packaging. Postharvest Biology Technology 39: 61-68.

Shi, C., Sun, G., Zhang, H., Xiao, B., Ze, B., Zhang, N. \& Wu, N. 2014. Effects of warming on chlorophyll degradation and carbohydrate accumulation of alpine herbaceous species during plant senescence on the Tibetan Plateau. PLOS ONE 9(9): 107874.

Spokowski, A.L. 2010. Effect of refrigerated vacuum storage on the shelf life of comingled broccoli, cauliflower, and carrots. MSc thesis, Clemson University, South Carolina, United States of America (Tidak diterbitkan).

Van Bree, I., De Meulenaer, B., Samapundo, S., Vermeulen, A., Ragaert, P., Maes, K.C., De Baets, B. \& Devlieghere, F. 2010. Predicting the headspace oxygen level due to oxygen permeation across multilayer polymer packaging materials: A practical software simulation tool. Innovative Food Science and Emerging Technology 11(3): 511-519.

Walkowiak-Tomczak, D. 2007. Changes in antioxidant activity of black chokeberry juice concentrate solutions during storage. Acta Scientiarum Polonorum Technologia Alimentaria 6(2): 49-54. 
Yahia, E.M., Soto-Zamora, G., Brecht, J.K. \& Gardea, A. 2007. Postharvest hot air treatment effects on the antioxidant system in stored mature-green tomatoes. Postharvest Biology and Technology 44(2): 107-115.

Zayapor, M.N., Abdullah, A. \& Mustapha, W.A.W. 2020. Antioxidant and anti-diabetic status of popular Malay health tonic consumed for wellness: help or hype? Sains Malaysiana 49(1): 145-154.

Jing Yi Ler, Arnida Hani Teh* \& Hafeedza Abdul Rahman Department of Food Sciences

Faculty of Science and Technology

Universiti Kebangsaan Malaysia

43600 UKM Bangi, Selangor Darul Ehsan

Malaysia
Arnida Hani Teh* \& Hafeedza Abdul Rahman

Innovation Center for Confectionary Technology (MANIS)

Faculty of Science and Technology

Universiti Kebangsaan Malaysia

43600 UKM Bangi, Selangor Darul Ehsan

Malaysia

*Pengarang untuk surat-menyurat; email: arnida@ukm.edu.my

Diserahkan: 15 Disember 2020

Diterima: 19 Februari 2021 